\title{
WOKÓŁ PRAWNEJ DEFINICJI SANKTUARIUM
}

Treść: Wstęp. - 1. Sanktuarium kościołem lub innym miejscem świętym. 2. Liczne pielgrzymowanie wiernych. - 3. Szczególna przyczyna pobożności. 4. Aprobata władzy kościelnej. - Wnioski.

\section{Wstęp}

15 sierpnia 2011 r. Kongregacja ds. Duchowieństwa opublikowała okólnik pt. List do kustoszy sanktuariów, gdzie m.in. czytamy: „Ojciec Święty Benedykt XVI (...) wielką uwagę przypisuje obecności Sanktuariów, cenną w Kościele, gdyż jako cel pielgrzymek, są one przede wszystkim miejscami «wezwania, które pociąga wciąż rosnącą liczbę pielgrzymów i turystów religijnych, znajdujących się często w skomplikowanych sytuacjach ludzkich i duchowych, wielu daleko od przeżywania wiary i wraz ze słabą przynależnością kościelną». Sanktuaria zatem są «znakiem żywego Chrystusa pośród nas, i w tym znaku chrześcijanie zawsze rozpoznawali inicjatywę Boga żywego względem ludzi»"”.

Choć „sanktuaria chrześcijańskie zawsze i wszędzie, były lub próbowały być znakami Boga, Jego interwencją w historię ludzkości”, a także miejscami uprzywilejowanymi ,w którym człowiek, pielgrzym na tej ziemi, doświadcza kochającej i zbawczej obecności Boga. W nim znajduje płodną przestrzeń, z dala od zajęć codziennych, gdzie może zebrać i odzyskać siły duchowe dla ponownego rozpoczęcia drogi wia-

${ }^{1}$ Lettera della Congregazione del Clero ai Rettori dei Santuari [15 agosto 2011], Premessa, Città del Vaticano 2011, tekst polski: KongregaCja DS. Duchowieństwa, List do kustoszy sanktuariów [15 sierpnia 2011], Anamnesis 17(2011) nr 4, s. 19-25. 
ry"2, to są one nie tylko rzeczywistością teologiczną i duszpasterską, ale również instytucją prawną.

Mimo, że miejsca święte zwane sanktuariami były od wieków rozpowszechnione w całym świecie katolickim, to brak było w tej kwestii stosownych przepisów prawnych. Stąd normy Kodeksu Prawa Kanonicznego z 1983 roku tyczące się sanktuariów są w stosunku do poprzedniej kodyfikacji nowością ${ }^{3}$.

Niniejszy artykuł podejmuje kwestię definicji sanktuarium z punktu widzenia prawa kanonicznego.

\section{Sanktuarium kościołem lub innym miejscem świętym}

Fenomen sanktuariów łączy się z kościołami lub kaplicami, czy innymi miejscami świętymi, do których wierni liczniej ściągają, niż do innych miejsc kultu.

W kan. 1230 prawodawca kodeksowy zamieszcza pojęcie sanktuarium. „Przez sanktuarium rozumie się kościół lub inne miejsce święte, do którego - za aprobatą ordynariusza miejscowego - pielgrzymują liczni wierni, z powodu szczególnej pobożności”. W przeciwieństwie do klasycznej paremii łacińskiej ukutej przez rzymskiego jurystę Iavolenusa Priscusa (ur. w latach 50 po Chrystusie - zm. po roku 106 po Chrystusie) zawartej w jego Liber XI Epistularum: omnis definitio in iure civili periculosa est: parum est enim, ut non subverti posset ${ }^{4}$

2 Tamże.

3 Trzeba jednak przypomnieć, że list Kongregacji Seminariów i Uniwersytetów z 1956 roku zawierał pojęcie sanktuarium niewiele różniące się od zamieszczonego w aktualnym Kodeksie. Sacra Congregatio de Seminariis et Universitatibus, Responsa Solvuntur dubia circa notionem «sanctuarii» [8 februarii 1956], Acta Apostolicae Sedis 52(1956), s. 660. Brak w KPK z 1917 roku przepisów prawnych regulujących dziedzinę sanktuariów wielokrotnie podkreślał papież Paweł VI, który już w 1970 roku zapewniał rektorów sanktuariów włoskich zebranych na kongresie narodowym, że w nowym Kodeksie będą zawarte normy odnoszące się do sanktuariów i pielgrzymek wiernych. Por. G. Feliciani, La disciplina canonica dei santuari, w: Profili giuridici e storia dei santuari cristiani in Italia, pod red. G. Dammacco, G. Otranto, Bari 2004, s. 31-32.

${ }^{4}$ Corpus Iuris Civilis, edit. J. Ausoult, Lugduni 1560, col. 1740, D., 50, 17, 202. C. Rosell zauważa, że sławna „reguła” Iavolenusa Priscusa przeszła także do Corpus 
(,Wszelka definicja w prawie cywilnym jest niebezpieczna, ponieważ rzadko kiedy nie można jej podważyć") prawodawca kodeksowy chciał jednak zdefiniować, sprecyzować, określić, co rozumie przez pojęcie „sanktuarium”.

Określenie sanktuarium zawarte w kan. 1230 KPK jest definicją szeroką, która jednocześnie określa okoliczności i warunki, które muszą występować (zachodzić), aby miejsce, które faktycznie jest celem pielgrzymek, mogło być uważane prawnie za sanktuarium ${ }^{6}$.

Należy przypomnieć, że przytoczone pojęcie sanktuarium, mimo iż jest nowe w stosunku do poprzedniego ustawodawstwa kodeksowego ${ }^{7}$, ma swoja historię.

$\mathrm{Na}$ powstanie kodeksowej definicji sanktuarium wpłynęły bardzo znacząco oficjalne wypowiedzi Kościoła. Trzeba przede wszystkim wspomnieć Dekret Kongregacji Soboru z 11 lutego 1936 roku De piis fidelium peregrinationibus ad celebriora sanctuaria moderandis ${ }^{8}$. Dokument ten jest wyrazem troski Stolicy Apostolskiej o utrzymanie religijnego charakteru pielgrzymek do sanktuariów wobec zagrożenia sekularyzacjąa9.

Iuris Canonici, bez przymiotnika civili, i z tego powodu jest bardzo często cytowana przez kanonistów, bez podejmowania się trudu podania jej źródła. Santuarios y Basílicas en el Derecho canónico vigente, Efemérides Mexicana 6(1988) nr 17, s. 167.

5 Zob. J. Martín de Agar, Comentario al cán. 1230-1234, w: Comentario exegético al Código de Derecho Canónico, pod red. A. Marzoa, J. Miras, R. Rodríguez-Ocaña, t. 3, cz. II, wyd. 3, Pamplona 2002, s. 1848.

${ }^{6}$ Por. tamże.

${ }^{7}$ Kodeks Prawa Kanonicznego z 1917 roku w kan. 2313 wskazywał jedynie na pielgrzymkę jako jedną z głównych pokut: $§ 1$. „Praecipuae poenitentiae sunt praecepta: $\mathrm{nr} 2$ „Peragendi piam aliquam peregrinationem vel alia pietatis opera”.

${ }^{8}$ Sacra Congregatio Concilit, Decretum De piis fidelium peregrinationibus ad celebriora sanctuaria moderandis [11 februarii 1936], Acta Apostolicae Sedis 28(1936), s. 167-168, X. Ochoa, Leges Ecclesiae post Codicem iuris canonici editae, vol. I, Roma 1966, col. 1710-1711.

9 J. DudZIAK pisze, że „Kongregacja Soboru wniosła tu przez omawiany dokument na sposób uboczny, ogólny co prawda, w kontekście pielgrzymek, wystarczająco zarysowaną koncepcję kanonistyczną sanktuarium. Dokument miał wszak charakter Dekretu, a więc wiążącej normy działania". Prawno-kanoniczna koncepcja sanktuarium, Tarnowskie Studia Teologiczne 9(1983), s. 63; por. M. Lo GıAcCo, Il pellegrinaggio: 
Autorzy wspomnianego dokumentu (dekretu) pisali: „wśród publicznych i wspólnych określeń chrześcijańskiej pobożności w Kościele katolickim, od najodleglejszych zatem czasów szczególne miejsce słusznie zajmują dla siebie pobożne pielgrzymki do sławniejszych sanktuariów poświęconych Bogu, błogosławionej Maryi Pannie, albo świętym, aby bardzo wiele przyczyniły się do czynienia pokuty, do wyznawania wiary i wzmocnienia jej, do składania dziękczynienia za otrzymane dobrodziejstwa"10.

Drugim oficjalnym wystąpieniem Stolicy Apostolskiej w materii sanktuariów w okresie pokodeksowym była decyzja (odpowiedź) Kongregacji Seminariów i Studiów Uniwersyteckich, wydana 8 lutego 1956 roku $^{11} \mathrm{~W}$ pewnej, anonimowej kwestii spornej ${ }^{12}$. W akcie tym zawarta została prawna definicja sanktuarium, której twórcą był sam Pius XII, gdyż ją osobiście przeanalizował, zaaprobował i polecił wprowadzić do nowego Kodeksu ${ }^{13}$.

Wspomniana definicja Piusa XII brzmiała: „Sanktuarium jest to kościół czyli sakralny budynek przeznaczony dla publicznego wykonywania kultu Bożego, który (np. z powodu cieszącego się czcią obrazu świętego, przechowywanych relikwii, zdziałanego przez Boga cudu,

profili giuridici, w: Profili giuridici e storia dei santuari cristiani in Italia, pod red. G. Dammacco, G. Otranto, Bari 2004, s. 92.

${ }^{10}$ Decretum De piis fidelium peregrinationibus, X. Ochoa, Leges Ecclesiae, Praefatio, k. 1710-1711; por. G. Feliciani, La disciplina canonica dei santuari, s. 31.

${ }^{11}$ Responsa Solvuntur dubia circa.

${ }^{12}$ Chodziło o sanktuarium prowadzone przez niewymieniony klasztor w pewnej diecezji, od którego Biskup Diecezjalny, znalazłszy się w finansowej potrzebie, zażądał [od klasztoru] uiszczenia także z dochodów sanktuaryjnych nałożonego na diecezję podatku seminaristicum. Szerzej zob. J. DudZIAK, Prawno-kanoniczna koncepcja sanktuarium, s. 64.

${ }^{13}$ Por. J. DudZIaK, Prawno-kanoniczna koncepcja sanktuarium, s. 64. Na audiencji udzielonej ówczesnemu audytorowi Roty Rzymskiej Dino Staffie, 22 grudnia 1955 roku, ten przedstawił Piusowi XII przygotowaną przez siebie definicję ,sanktuarium”; papież po jej uważnym przeczytaniu zaaprobował ją dodając: „ta definicja wejdzie do nowego Kodeksu prawa kanonicznego" [„,questa definizione entrerà nel nuovo Codice di Diritto Canonico"]. D. STAFFA, De notione sanctuarii et de ipsius obligatione solvendi tributum pro seminario, Apollinaris 49(1976) nr 1-2, s. 256; por. C. RoselL, Santuarios y Basílicas, s. 163. 
możliwości zyskiwania specjalnych odpustów) jest przez lud wierny ustanowiony celem pielgrzymek, dla uproszenia łask lub wyrażenia za nie podziękowania"14.

Trzeba dodać, że już w po soborze Watykańskim II Stolica Apostolska zajęła się materią dotyczącą sanktuariów, także poprzez dyspozycje mające charakter ogólny, domagając się od ordynariuszy podnoszenia szacunku „dla sanktuariów znajdujących się w diecezji zarówno $\mathrm{z}$ uwagi na ich wielki wkład, jaki one wnoszą w rozdawnictwo Sakramentów Pokuty i Eucharystii, jak na wrażenie, jakie wywierają na turystów nawet nie praktykujących" 15 oraz troski, aby „sanktuaria, wzniesione ku czci Boga, Matki Najświętszej czy ku czci świętych (...) przyczyniały się (...) w sposób skuteczny do spotęgowania i rozwoju życia duchowego diecezji"16.

Wracając do kan. 1230 należy stwierdzić, że do zaistnienia sanktuarium konieczne jest przede wszystkim, aby było to miejsce święte: „kościół lub inne miejsce święte”.

Sanktuarium w sensie prawnym musi być miejscem świętym, zwykle kościołem. Jest to rzeczywistość fizyczna, określona jako ecclesia vel alius locus sacer. „Miejscami świętymi są te, które przez poświęcenie lub błogosławieństwo, dokonane według przepisów ksiąg liturgicznych, przeznacza się do kultu Bożego lub na grzebanie wiernych"17.

${ }^{14}$ „Sanctuarii nomine intelligitur Ecclesia seu aedes sacra divino cultui exercendo dicata, quae ob peculiarem pietatis causam [ex. gr. ob imaginem sacram ibi veneratam, ob reliquiam ibi conditam, ob miraculum, quod Deus ibi operatus sit, ob peculiarem indulgentiam ibi lucrandam], a fidelibus constituitur meta peregrinationum ad gratias impetrandas vel vota solvenda". Zob. G. Feliciani, La disciplina canonica dei santuari, s. 32.

${ }^{15}$ SaCra Congregatio pro Clericis, Directorium generale pro ministerio pastorali quoad turismum Peregrinans in terra [30 aprilis 1969], cz. II B, d, Acta Apostolicae Sedis 61(1969), 361-384, tekst polski: Posoborowe Prawodawstwo Kościelne, t. II, z. 2, nn. 2769-2932. Trzeba dodać, że zarówno dekret De piis fidelium z 1936 roku i Respopnsa z 1956 roku są źródłami obecnego kan. 1230. Pontificia Commissio Codici Iuris Canonici Authentice Interpretando, Codex Iuris Canonici Auctoritate Ioannis Pauli PP. II promulgatus. Fontium annotatione et indice analitico-alphabetico auctus, Libreria Editrice Vaticana 1989, przypis do kan. 1230, s. 332.

${ }^{16}$ Sacra Congregatio pro Episcopis, Directorium Ecclesiae imago de pastorali ministerio Episcoporum [22 februarii 1973], nr 90b, Typis Polyglottis Vaticanis 1973; por. G. Feliciani, La disciplina canonica dei santuari, s. 32.

${ }^{17}$ Kan. 1205. 
Bardzo często sanktuarium w swoich początkach jest kaplicą a następnie, w miarę jak wzmagał się napływ wiernych, budowano kościół, lecz nie zawsze tak musi być. Najczęściej sanktuaria są kościołami, czyli budowlami świętymi przeznaczonymi dla kultu Bożego, do których wierni mają prawo wstępu w celu wykonywania w niej kultu, zwłaszcza publicznego ${ }^{18}$. Faktycznie przeważająca większość sanktuariów stanowią kościoły, gdyż albo takimi były już od początku swego istnienia bądź zbudowano je później, jako odpowiedź na życzenia i wymagania pobożnych pielgrzymów. Jednakże sanktuaria nie zawsze muszą być kościołami, kaplicami czy kaplicami prywatnymi. Mogą być: placem, cmentarzem, grotą, źródłem, szczytem góry, które często, jak pokazuje historia, zostały spontanicznie uświęcone przez pobożność wiernych pielgrzymów, skłaniając następnie władzę kościelną do kanonicznego zatwierdzenia tych miejsc ${ }^{19}$.

Warto dodać, że w pierwszej prawnej definicji sanktuarium autorstwa Dino Staffy z 1956 roku (zatwierdzonej przez Piusa XII) sanktuarium stanowił jedynie ecclesia seu aedes sacra divino cultui exercendo dicta (kościół czyli sakralny budynek przeznaczony dla publicznego wykonywania kultu Bożego) ${ }^{20}$.

W schemacie Kodeksu z 1977 roku ,sanktuarium oznacza budowlę lub miejsce święte przeznaczone dla publicznego wykonywania w nich kultu Bożego" "21. Jednak w czasie dyskusji nad kan. 24 schematu z 1977 roku (w dniach 1-6 października 1979 roku), zgłoszono propozycję ecclesia vel loca sacra divino cultui dicata. Propozycja ta

${ }^{18}$ Por. kan. 1214.

${ }^{19}$ Por. M. Lo Giacco, Pellegrini, Romei e Palmieri. Il pellegrinaggio fra diritto e religione, Bari 2008, s. 158; G. Feliciani, La disciplina canonica dei santuari, s. 37-38; C. Rosell, Santuarios y Basílicas, s. 167-168.

${ }^{20}$ Responsa Solvuntur dubia circa, s. 660. J. DudzIAK pisze, że sanktuarium „musi to być kościół, nie wystarczy kaplica - ecclesia seu aedes sacra. Najwyraźniej bowiem ma tu sens wyjaśniający a nie rozłączny partykuła seu. Prawno-kanoniczna koncepcja sanktuarium, s. 66.

${ }^{21}$ „Sanctuarii nomine intelliguntur aedés vel loca sacra divino cultui publice exércendo dicata". Pontificia Commissio Codici Iuris Canonici Recognoscendo, Schema canonum Libri IV, De Ecclesiae munere sanctificandi, pars II, De locis et temporibus sacris deque cultu divino, Typis Polyglottis Vaticanis 1977, can. 24. 
okazała się zadowalająca dla konsultorów i przyjęto termin ecclesia zamiast aedes $^{22}$. Stąd w schemacie z 1980 roku zapisano, że ,sanktuarium oznacza kościół lub inne miejsce święte"23. Takie sformułowanie pozostało w schemacie Kodeksu z 1982 roku $^{24}$ i w KPK z 1983 roku² ${ }^{25}$.

Sanktuarium w sensie prawnym musi być więc kościołem lub innym miejscem świętym, gdzie liczni pielgrzymi znajdują nadprzyrodzone pomoce, niezależnie od tego, że z sanktuarium mogą być połączone inne pomieszczenia takie jak np. dom, gdzie urodził się albo żył święty, szpital, dom rekolekcyjny itp. Tak długo jak ośrodek pielgrzymkowy nie jest miejscem świętym w sensie kan. 1205, to chociaż wykonuje się tam kult Boży i ma miejsce opieka duchowa nad pielgrzymami, to nie istnieje jeszcze sanktuarium w sensie właściwym (prawnym). Oczywiście, nic nie przeszkadza, aby do kościoła albo kaplicy, który nie jest prawnie sanktuarium, przybywali pielgrzymi z powodu jakiejś przyczyny pobożności ${ }^{26}$.

\section{Liczne pielgrzymowanie wiernych}

Kan. 1230 definiuje sanktuarium jako kościół lub inne miejsce święte, do którego pielgrzymują liczni wierni. Bowiem ,pielgrzymowanie pozostaje w ścisłym związku z sanktuarium jako bardzo rozpowszechniony i charakterystyczny wyraz pobożności ludowej"27. Pielgrzymka będąca powszechną formą religijności, ,jest typowym wyrazem reli-

${ }^{22}$ Pontificia Commissio Codici Iuris Canonici Recognoscendo, Communicationes 12(1980) nr 2, s. 319-341; por. C. Rosell, Santuarios y Basílicas, s. 165.

${ }^{23}$ Pontificia Commissio Codici Iuris Canonici Recognoscendo, Schema Codicis Iuris Canonici, Libreria Editrice Vaticana 1980, can. 1181.

${ }^{24}$ Codex Iuris Canonici, Schema novissimum iuxta placita Patrum Commissionis emendatum atque Summo Pontifici praesentatum, Typis Polyglottis Vaticanis 1982, can. 1230.

${ }^{25}$ Kan. 1230.

${ }^{26}$ Por. Congregatio de Cultu Divino et Disciplina Sacramentorum, Direttorio su pietà popolare e liturgia. Principi e orientamenti [17 decembris 2001], nr 264, Città del Vaticano 2002, tekst polski: Kongregacja Kultu Bożego i DyscyPliny SaKraMENTów, Dyrektorium o pobożności ludowej i liturgii. Zasady i wskazania, Poznań 2003, [dalej: DPL]; por. J. Martín DE AgAR, Comentario al cán. 1230-1234, s. 1848.

${ }^{27}$ DPL, nr 261. 
gijności ludowej, ściśle związanej z sanktuarium, którego istnienie stanowi element konieczny. Pielgrzym potrzebuje sanktuarium, a sanktuarium potrzebuje pielgrzyma" ${ }^{28}$.

Tak więc liczne pielgrzymowanie do określonego kościoła lub innego miejsca świętego stanowi kolejny człon prawnego określenia sanktuarium.

Z definicji sanktuarium z kan. 1230 wyłania się przyczyna sprawcza, a więc czynniki, które dane sanktuarium tworzą. Wymieniona przyczyna zawiera dwa elementy składowe: materialny i formalny.

J. Dudziak pisze: ,przyczynę materialną stanowią określone formy kultu wiernych, a mianowicie muszą to być «częste pielgrzymowania» wiernych. Tak bowiem wypada nam rozumieć owe formy kultu określone w omawianym kanonie nowego Kodeksu: fideles frequentes... peregrinantur. Przez fideles frequentes trzeba rozumieć w każdym razie liczniejsze, wpadające w oko ilości wiernych. Nie powiedziano tu jednak, że muszą to być tłumy. Rzecz jest na pewno do oceny w stosunku do okoliczności miejsca i czasu. A więc, jaki jest stan zaludnienia w danym regionie, jakie są warunki komunikacji, itp. Ponadto fideles frequentes - trzeba także niewątpliwie rozumieć w sensie częstotliwości, ciągłości pielgrzymowania do danego miejsca. Nie czyniłyby tu więc zadość peregrynacje, choćby tłumne, lecz przejściowe, nie posiadające charakteru stabilności. I przeciwnie, chociażby te peregrynacje nie były tak tłumne ilościowo, lecz gdy są stałe, spontaniczne, nie narzucone z góry, nie wymuszone, spełniają one zapewne zamierzony wymóg prawa" 29 .

Definicja sanktuarium przedłożona w kan. 1230 KPK ma tę zaletę, że umieszcza na pierwszym planie tę właściwość sanktuarium, która odróżnia je wyraźnie od każdego innego miejsca świętego. Wspomnianą cechę charakterystyczną sanktuarium można tak opisać: powstanie i istnienie (trwałość) sanktuarium nie są określane przez autorytet kościelny, ale przez pobożność ludową, czyli pobożność ludzi, która skłania ich do udania się w drogę indywidualnie czy w grupie.

\footnotetext{
${ }^{28}$ Tamże, nr 279.

${ }^{29}$ Prawno-kanoniczna koncepcja sanktuarium, s. 69.
} 
To przybywanie do określonego miejsca świętego przyjmuje nazwę pielgrzymki ${ }^{30}$. Tak zatem źródło wszystkich sanktuariów znajduje się w pobożności ludowej, w pobożności, którą wzbudza w wiernych określone miejsce, a w nim szczególna przyczyna pobożności. Fenomen ten spowoduje w konsekwencji w drugim etapie, działanie władzy kościelnej w postaci aprobaty. A więc sanktuarium nie powstaje na mocy dekretu, ani nie jest tytułem, który nadaje władza kościelna (tak jak w przypadku bazyliki mniejszej), lecz jest rzeczywistością, która rodzi się z pobożności ludowej ${ }^{31}$.

W związku z tym S. De Fiores zauważa, że sanktuarium istnieje o tyle, o ile przybywają do niego pielgrzymi. Kiedy ustaje napływ pielgrzymów, przestaje istnieć także sanktuarium ${ }^{32}$. Bowiem ,pielgrzymka (...) jest ściśle związana z sanktuarium, którego istnienie stanowi element konieczny. Pielgrzym potrzebuje sanktuarium, a sanktuarium potrzebuje pielgrzyma" ${ }^{\prime 3}$.

Trzeba zauważyć, że wprowadzając do Kodeksu nową figurę (instytucję) sanktuariów prawodawca nie ustanowił nowego typu miejsca kultu, odrębnego od kościołów, kaplic i kaplic prywatnych, gdyż sanktuaria w aspekcie fizycznym nie odróżniają się od tych miejsc świętych, głównie od kościołów. Prawodawca chciał ukazać, że sanktuaria charakteryzują się tym, iż pielgrzymują do nich za aprobatą ordynariusza miejscowego liczni wierni, z powodu szczególnej przyczyny pobożności ${ }^{34}$.

${ }^{30}$ Por. G. Feliciani, La disciplina canonica dei santuari, s. 33; M. Lo Giacco, Pellegrini, Romei e Palmieri, s. 157-158.

${ }^{31}$ Por. X. Brossa, Régimen jurídico de los santuarios en el CIC, Roma 1996, s. 108.

${ }^{32}$ L'emergere dei Santuari nella coscienza della Chiesa: significato e responsabilità, La Madonna 32(1984) nr 1-2, s. 26; por. G. Feliciani, La disciplina canonica dei santuari, s. 33.

${ }^{33}$ DPL, nr 279.

${ }^{34}$ Por. X. Brossa, Régimen jurídico, s. 126; J. Martín de Agar, Comentario al cán. 1230-1234, s. 1848. C. Rosell stwierdza, że ,istotą sanktuarium” jest przymiot, który występuje tylko w określonych kościołach albo miejscach świętych, i tylko jedynie w tych, do których, z powodu szczególnej przyczyny pobożności, przybywa w pielgrzymce za aprobatą ordynariusza miejsca znaczna liczba wiernych. Santuarios y Basílicas, s. 169-170. 
Wypada zaznaczyć, że w analizowanym kan. 1230 nie ma żadnej wzmianki o wymaganej długotrwałości wspomnianego pielgrzymowania do danego miejsca świętego dla nadania mu charakteru sanktuarium. Wolno sądzić, iż czas ten winien wynosić przynajmniej 30 lat, tzn. tyle ile aktualny KPK wymaga do wytworzenia się zwyczaju prawnego $^{35}$. Oczywiście ordynariusz miejsca określi ten czas z całą roztropnością, będzie mógł go niekiedy nawet skrócić.

J. Dudziak zauważa, że „w określeniu aktów kultu zdatnych do wytworzenia sanktuarium, użyto w nowym Kodeksie wyrażenia, że muszą to być «czyny pątnicze, pielgrzymie» - fideles frequentes... peregrinantur. Dla pielgrzymowania została tu zapewne świadomie użyta formuła ogólna. Mogą tu więc wchodzić w rachubę zarówno pielgrzymki grupowe, publiczne, jak też prywatne, indywidualne. Natomiast o wiele ważniejszym, niż ten zewnętrzny styl pielgrzymki, jest jej wymiar wewnętrzny. Chodzi mianowicie o to, by wierni posiadali ducha pielgrzymowania, postawę, żeby nie powiedzieć tradycyjnie, intencję. Taką zaś postawę posiadają oni wówczas, gdy udają się do danego sanktuarium ze szczerą wolą spotkania z Bogiem w tej tajemnicy, jaką ono reprezentuje, ze szczerą wolą wewnętrznej przemiany, pogłębienia życia chrześcijańskiego, wzmocnienia postawy apostolskiej, gdy tam się spowiadają, przyjmują Komunię św. i biorą udział w urządzanych tam nabożeństwach. Nie ma wątpliwości, że wymagane przez prawo «akty pielgrzymie, pątnicze», należy tak właśnie personalistycznie rozumieć"36.

\section{Szczególna przyczyna pobożności}

Kan. 1230 definiując prawnie sanktuarium stwierdza, że jest to „kościół lub inne miejsce święte, do którego (...) pielgrzymują liczni wierni, z powodu szczególnej pobożności”.

${ }^{35}$,Jeśli nie uzyskał specjalnego zatwierdzenia kompetentnego prawodawcy, zwyczaj przeciwny obowiązującemu prawu kanonicznemu oraz zwyczaj obok prawa kanonicznego jedynie wtedy otrzymuje moc prawa, gdy jest zachowywany zgodnie z prawem w sposób ciągły przez pełnych lat trzydzieści”. Kan. 26 KPK; por. J. DuDZIAK, Prawno-kanoniczna koncepcja sanktuarium, s. 69; X. Brossa, Régimen jurídico, s. 120.

${ }^{36}$ Prawno-kanoniczna koncepcja sanktuarium, s. 69-70. 
Mówiąc o motywie peregrynowania do określonego miejsca świętego należy poczynić pewne uwagi odnoszące się do kluczowego w sprawie pielgrzymek i sanktuariów kan. 1230 KPK. W pierwszej wersji oficjalnego thumaczenia KPK na język polski, zatwierdzonej przez Konferencję Episkopatu Polski 9 kwietnia 1983 roku $^{37}$, przywołany kanon brzmi: ,przez sanktuarium rozumie się kościół lub inne miejsce święte, do którego - za aprobatą ordynariusza miejscowego - pielgrzymują liczni wierni, z powodu szczególnej pobożności"38. Według tego thumaczenia wierni udają się do sanktuarium ,z powodu szczególnej pobożności". Na pierwszy rzut oka wydaje się, że wierni pielgrzymują, gdyż odznaczają się „,szczególną pobożnością”. Jest to jednak thumaczenie niekompletne, a przez to nieprecyzyjne, wręcz mylące, zmieniające sens przywołanej normy prawnej ${ }^{39}$.

Dyrektorium o pobożności ludowej w polskim thumaczeniu również przytacza niekompletne tłumaczenie kan. $1230 \mathrm{z}$ polskiego thumaczenia Kodeksu ${ }^{40}$. Natomiast Direttorio su pietà popolare e liturgia $\mathrm{w}$ języku włoskim (a więc w oryginale) zawiera kan. $1230 \mathrm{w}$ poprawnym thumaczeniu: „Per santuario si intendono una chiesa o un altro luogo sacro, a cui, per speciali motivi di pietà (wyróżnienie moje J. A), con l'approvazione dell'Ordinario del luogo, i fedeli fanno pellegrinaggio in grande numero"41. Także wersja hiszpańska Dyrektorium o pobożno-

\footnotetext{
${ }^{37}$ Kodeks Prawa Kanonicznego, przekład polski zatwierdzony przez Konferencję Episkopatu, Poznań 1984.

${ }^{38}$ To samo thumaczenie jest w wydaniu: Kodeks Prawa Kanonicznego, przekład polski zatwierdzony przez Konferencję Episkopatu, Poznań 2008.

${ }^{39}$ Jeszcze bardziej mylące jest thumaczenie kan. 1230 w publikacji: Codex Kodeks Prawa Kanonicznego, Komentarz. Powszechne i partykularne ustawodawstwo Kościoła Katolickiego. Podstawowe akty polskiego prawa wyznaniowego. Edycja polska na podstawie wydania hiszpańskiego, pod red. P. Majera, Kraków 2011, gdzie na s. 913 czytamy: „Przez sanktuarium rozumie się kościół lub inne miejsce święte, do którego - za aprobatą ordynariusza miejsca - pielgrzymują liczni wierni, kierujący się szczególną pobożnością".

${ }^{40} \mathrm{DPL}$, nr 264, nr 279 przypis 35.

${ }^{41}$ Congregatio de Cultu Divino et Disciplina Sacramentorum, Direttorio su pietà popolare e liturgia. Principi e orientamenti, [17 dicembre 2001], nr 264, Città del Vaticano 2002.
} 
ści ludowej zawiera poprawne tłumaczenie tekstu kan. 1230: „Con el nombre de santuario se designa una iglesia u otro lugar sagrado al que, por un motivo peculiar de piedad (wyróżnienie moje J. A), acuden en peregrinación numerosos fieles, con aprobación del Ordinario del lugar" 42 .

Kodeks Prawa Kanonicznego z 1983 roku w tłumaczeniu na język hiszpański zawiera poprawne thumaczenie por un motivo peculiar de piedad $^{43}$, jak również $\mathrm{w}$ tłumaczeniu włoskim per speciali motivi di pietà ${ }^{44}$.

W wersji łacińskiej kanon ten brzmi: Sanctuarii nomine intelleguntur ecclesia vel alius locus sacer ad quos, ob peculiarem pietatis causam, fideles frequentes, approbante Ordinario loci, peregrinantur. Porównanie teksu oryginalnego z zaprezentowaną translacją polską pozwala bez trudności zauważyć, że w polskiej wersji pominięto kluczowe dla definicji sanktuarium słowo causa (causa, -ae - przyczyna, czynnik, zasada, powód, pobudka) ${ }^{45}$. Analiza gramatyczna tekstu łacińskiego pozwala stwierdzić, że przydawka przymiotna peculiaris jest połączona i odnosi się do causa (przyczyna), nie do pietas. Tą przyczyną jest motyw pobożności, z powodu którego wierni udają się do sanktuarium: jest nim obraz, odpusty, relikwie itd. ${ }^{46}$ Stąd $o b$ peculiarem pietatis causam należy tłumaczyć: ,z powodu szczególnej przyczyny pobożności”, ,szczególnej przyczyny związanej z pobożnością" ${ }^{47}$. Trzeba także pamiętać, że normy poprzedzające obecny kan.

${ }^{42}$ Congregación para el Culto Divino y la Disciplina de los Sacramentos, Directorio sobre la piedad popular y la liturgia. Principios y orientaciones [17 diciembre 2001], nr 264, Ciudad del Vaticano 2002.

${ }^{43}$ Código de Derecho Canónico. Edición bilingüe, fuentes y comentarios de todos los cánones, pod red. A. Benlloch Poveda, Valencia 1993, can. 1230.

${ }^{44}$ Codice di Diritto Canonico commentato. Testo ufficiale latino. Traduzione italiana. Fonti interpretazioni autentiche. Legislazione complementare della Conferenza Episcopale Italiana, Milano 2001, can. 1230.

${ }^{45}$ A. Jougan, Słownik kościelny łacińsko-polski, Warszawa 1992, s. 97.

${ }^{46}$ Por. C. Rosell, Santuarios y basílicas, s. 168. Na temat przyczyny pobożności będzie mowa na dalszych stronach niniejszego artykułu.

${ }^{47}$ Trudno zrozumieć, że mimo, iż autor tłumaczenia polskiej wersji KPK ks. prof. E. Sztafrowski poprawnie przełożył z łaciny na polski schematy obecnego kan. 1230 
1230 zawierały sformułowanie o szczególnej przyczynie pobożności: peculiaris pietatis causa ${ }^{48}$.

Cechą charakterystyczną właściwą jedynie sanktuariom jest to, że przybywają tam wierni w pielgrzymce przyciągani przez konkretną przyczynę pobożności. Przyczyna ta musi wyzwalać i motywować pobożność wiernych tam się udających. To jest właśnie to, co odróżnia sanktuaria od innych miejsc kultu. Przyczyny, z powodu których wierni odbywają pielgrzymkę do sanktuariów, są bardzo różne: cuda, objawienia, miejsce upamiętniające jakieś ważne wydarzenie z historii zbawienia, czy związane z życiem świętych, obrazy, figury, albo relikwie, które cieszą się specjalną czcią ludu, uzyskanie odpustów, itp. Każde sanktuarium ma sobie właściwą przyczynę pobożności, która thumaczy napływ pielgrzymów ${ }^{49}$.

Definicja Dino Staffy z 1956 roku wylicza egzemplarycznie niektóre przyczyny pobożności istniejące $\mathrm{w}$ sanktuariach: cieszący się czcią obraz święty, przechowywane relikwie, zdziałany przez Boga cud, możliwość zyskiwania specjalnych odpustów ${ }^{50}$.

Schema canonum Libri IV, De Ecclesiae munere sanctificandi w kan. 24 wymienia nastepujące przyczyny pielgrzymowania: pamiąt-

- „Z racji szczególnej przyczyny związanej z pobożnością”: kan. 24 schematu KPK z 1977 roku i identycznie: kan. 1181 schematu KPK z 1980 roku [E. SzTAFrowsKI, Miejsca i czasy święte, Warszawa 1982, s. 247 i 254], to w wersji oficjalnego thumaczenia KPK na język polski z 1984 roku i 2008 roku kan. 1230 nie uwzględnia owej causa [pietatis].

${ }^{48}$ Responsa Solvuntur dubia circa, s. 660; zob. kanon zaproponowany na trzeciej sesji zespołu studyjnego konsultorów na temat miejsc, czasów świętych i kultu Bożego, która miała miejsce w Rzymie, od 16 do 20 października 1972 roku „Communicationes" 4 (1972), s. 166; Schema canonum Libri IV, De Ecclesiae munere sanctificandi 1977, can. 24; Pontificia Commissio Codici Iuris Canonici Recognoscendo, Schema Codicis Iuris Canonici, Libreria Editrice Vaticana 1980, kan. 1181. Ten ostatni tekst wszedł bez zmian do Codex Iuris Canonici, Schema novissimum iuxta placita Patrum Commissionis emendatum atque Summo Pontifici praesentatum, Typis Polyglottis Vaticanis 1982, can. 1230, i także bez zmian do obecnego KPK, jako kan 1230; por. X. Brossa, Régimen jurídico, s. 99-100; C. Rosell, Santuarios y basílicas, s. 170.

${ }^{49}$ Por. J. Dyduch, Pielgrzymowanie do sanktuariów $w$ świetle przepisów kościelnych, Geografia i Sacrum 1(2005), s. 213-214.

${ }^{50}$ Por. Responsa Solvuntur dubia circa, s. 660. 
ki religijne, czczony obraz, przechowywane znaczne relikwie, zdziałany cud.

Te przedmioty i wartości, które do danego kościoła ściągają specjalnie wiernych, prawodawcy wyliczali przykładowo, a nie wyczerpująco. Trzeba przypomnieć, że redagując kan. 1230 Komisja do spraw rewizji KPK otrzymała propozycję, by określić bliżej bezpośredni przedmiot kultu sanktuaryjnego, jako: sławny ze czci obraz, figurę, relikwie słynniejsze, zdziałanie cudu, itp. Jednakże w ostatecznej dyskusji Zespół Konsultorów uznał, iż mimo wszystko byłyby to tylko przykłady, które nie wyczerpywałyby zagadnienia, lub gdyby je wyliczać to lista ich byłaby zbyt długa, stąd lepiej jest ująć kwestię w ogólne sformułowanie: „szczególna przyczyna pobożności”. Komisja poszła za tą sugestią konsultorów ${ }^{51}$. Stąd w schematach KPK i w aktualnym Kodeksie mówi się już tylko o „ogólnej przyczynie pobożności” ${ }^{2}$, która obejmuje wszystkie możliwe motywy pobożnego pielgrzymowania.

Każde sanktuarium ma jakąś wyraźną przyczynę pobożności i zazwyczaj rozpowszechnia kult, który przyciąga licznych pielgrzymów (np. są niezliczone sanktuaria zadedykowane Najświętszej Maryi Pannie pod różnymi tytułami, lecz jest także wiele sanktuariów, gdzie się czci relikwie świętego i rozszerza się jego cześć $)^{53}$.

\section{Aprobata władzy kościelnej}

Każde sanktuarium potrzebuje do swego istnienia w sensie kanonicznym aprobaty kompetentnej władzy kościelnej. „Warunkiem wstępnym do tego, by jakieś miejsce święte zostało kanonicznie uznane za sanktuarium diecezjalne, narodowe lub międzynarodowe, jest odpowiednia aprobata biskupa diecezjalnego, Konferencji Biskupów lub Stolicy Apostolskiej. Zatwierdzenie kanoniczne stanowi oficjalne uznanie miejsca świętego i jego specyficznego przeznaczenia, upo-

${ }^{51}$ Por. Communicationes 12(1980) nr 2, s. 342; por. J. DudZIAK, Prawno-kanoniczna koncepcja sanktuarium, s. 68; X. BRossA, Régimen jurídico, s. 111.

${ }^{52}$ Schema Codicis Iuris Canonici 1980, can. 1181; Schema novissimum 1982, can. 1230; KPK z 1983 roku kan. 1230.

${ }^{53}$ Por. X. Brossa, Régimen jurídico, s. 111. 
ważnia je do przyjmowania pielgrzymów ludu Bożego, którzy się tam udają, by wielbić Ojca, wyznawać swoją wiarę, pojednać się z Bogiem, z Kościołem i z bliźnimi oraz błagać o wstawiennictwo Matkę Bożą lub świętego" 54 .

Prawodawca kodeksowy chciał, aby jednym z istotnych elementów sanktuarium była aprobata ordynariusza miejsca, do którego należy czuwanie nad celem duchowym sanktuarium, jak również zapobieganie możliwym dewiacjom u wiernych albo pielgrzymów, które mogą mieć - przez to, są pozbawione właściwej przyczyny pobożności charakter zabobonny albo fanatyczny ${ }^{55}$.

W czasie dyskusji nad kan. 24 Schema z 1977 roku w dniu 6 października 1979 roku, rozpatrywano uwagę przedstawioną przez organy konsultacyjne. Wspomniana uwaga zawierała propozycję uwzględnienia interwencji ordynariusza miejsca przy konstytuowaniu sanktuarium. Jeden z konsultorów wyraził opinię, iż tego rodzaju wzmianka nie jest konieczna, gdyż zazwyczaj interwencja władzy kościelnej następuje post factum. Inni konsultorzy chociaż przyznali, iż chronologicznie rzeczywiście aprobata następuje sukcesywnie (gdy sanktuarium już istnieje faktycznie) to jednak stwierdzili, że aprobata władzy kościelnej jest niezbędna, aby sanktuarium mogło istnieć prawnie ${ }^{56}$.

G. Feliciani pisze: ,jeśli pielgrzymki wiernych do określonych miejsc [jako praktyki pobożności osobistej, prywatnej] nie wymagają żadnego wyraźnego zatwierdzenia, to aprobata ukazuje się jako konieczna, aby określone miejsce mogło być uważane jako sanktuarium w systemie kanonicznym" ${ }^{57}$.

Ordynariusz miejsca jest odpowiedzialny - motywując się roztropnością i troską duszpasterską - za zbadanie faktów, które uzasadniają pielgrzymki i właściwą ich ocenę, jak również winien wyrazić swoją

${ }^{54}$ DPL, nr 264.

${ }^{55}$ Por. X. Brossa, Régimen jurídico, s. 118.

${ }^{56}$ Por. Communicationes 12(1980) nr 2, s. 342; por. G. Feliciani, La disciplina canonica dei santuari, s. 34; M. CALVI, I santuari nel nuovo Codice di diritto canonico, Quaderni di diritto ecclesiale 2(1989) nr 2, s. 182-183.

${ }^{57}$ Santuario, w: Enciclopedia del Diritto, pod red. G. Landi, S. Lariccia, F. Piga, t. 41, Varese 1989, s. 300. 
opinię o ich zgodności z wiarą i z obyczajami. Ordynariusz aprobując pielgrzymki wiernych do określonego miejsca, pośrednio wyraża także w ten sposób sąd o zgodności motywu pobożności z wiarą i obyczajami, który powoduje wspomniane pielgrzymki. Z drugiej strony stosowne jest rozróżnienie aprobaty pielgrzymek, od opinii kościelnej o określonych objawieniach albo cudach. Czasami Kościół powodując się roztropnością nie wypowiada się, przynajmniej w wystarczająco długim czasie, o autentyczności objawień, lecz jednocześnie może aprobować - przynajmniej milcząco - pielgrzymki ${ }^{58}$.

Aprobata ordynariusza miejsca rodzi podwójny skutek: z jednej strony przyznaje autentyczność kościelną pobożności pielgrzymów we wszystkich aspektach, od ortodoksji do szacunku dla dyscypliny kościelnej, a z drugiej, podporządkowuje miejsce kultu dyspozycjom kodeksowym i pozakodeksowym dedykowanym sanktuariom ${ }^{59}$.

C. Rosell twierdzi, że omawiana aprobata może być domyślna oraz niewyraźna, milczącą albo ustna, zawarta nawet w zachowaniu ordynariusza miejsca: w postawie życzliwości dla sanktuarium albo po prostu pozwoleniu na funkcjonowanie tego ośrodka kultu, poprzez to, że się temu nie sprzeciwia, w sposób podobny do wprowadzenia zwyczaju $^{60}$. Może więc to być aprobata zezwalająca, tolerująca, permi-

${ }^{58}$ Por. X. Brossa, Régimen jurídico, s. 118-119. Kościół bada w sposób wyczerpujący działania nadprzyrodzone i objawienia i maksymalnie jest ostrożny nim wyrazi swój sąd o tych sprawach. Np. pomimo pielgrzymek wiernych, do 13 maja 1930 roku nie były zadeklarowane przez biskupa Leiria jako prawdziwe objawienia w Fatimie, co by pozwalało na kult urzędowy Matki Bożej Różańcowej w Fatimie. Por. X. Brossa, Régimen jurídico, s. 108. W Polsce takim przykładem jest sanktuarium w Gietrzwałdzie. 27 czerwca 1877 roku dwóm warmińskim dziewczynkom objawiła się Matka Boża, co zapoczątkowało jeszcze większy wzrost kultu Najświętszej Maryi Panny, także poprzez przybywanie licznych pielgrzymów. Dopiero 11 września 1977, Biskup Warmiński Józef Drzazga, zatwierdził kult objawień w Gietrzwałdzie, ,jako nie sprzeciwiający się wierze i moralności chrześcijańskiej, oparty na faktach wiarygodnych, których charakter nadprzyrodzony i Boży nie da się wykluczyć". ARCYBISKUP Metropolita Warmiński, Dekret potwierdzający istnienie sanktuarium Matki Bożej Gietrzwałdzkiej w Gietrzwałdzie [27 czerwca 2002], Warmińskie Wiadomości Archidiecezjalne 57(2002) nr 60, s. 9-10.

${ }^{59}$ G. Feliciani, La disciplina canonica dei santuari, s. 35.

${ }^{60}$ Por. C. Roseli, Santuarios y basílicas, s. 169; X. Brossa, Régimen jurídico, 
sywna $^{61}$, ale jak zaznacza X. Brossa jest niezbędna, ,,aby sanktuarium mogło istnieć prawnie, a zatem, aby określone miejsce święte mogło być uważane prawnie za sanktuarium" 62 .

Warto dodać, że możliwe jest, aby ordynariusz miejsca mógł - w jakimś konkretnym wypadku - wycofać aprobatę sanktuarium, czy uzależniać ją od spełnienia przez tytulariuszy sanktuarium określonych warunków ${ }^{63}$.

Kompetentną władzą do zaaprobowania sanktuarium diecezjalnego jest ordynariusz miejsca ${ }^{64}$. W przypadku sanktuariów narodowych i międzynarodowych, potrzeba nowej aprobaty (Konferencja Biskupów i Stolica Apostolska), która oczywiście nie unieważnia zatwierdzenia na poziomie diecezjalnym ${ }^{65}$.

\section{Wnioski}

1. Choć sanktuaria chrześcijańskie są znakami Boga i Jego interwencji w historię ludzkości, to są one nie tylko rzeczywistością teologiczną i duszpasterską, ale również instytucją prawną.

2. Do zaistnienia sanktuarium konieczne jest przede wszystkim, aby było to miejsce święte: kościół lub inne miejsce święte.

3. Pielgrzymowanie pozostaje $\mathrm{w}$ ścisłym związku $\mathrm{z}$ sanktuarium. Pielgrzym potrzebuje sanktuarium, a sanktuarium potrzebuje pielgrzyma.

4. Sanktuarium istnieje o tyle, o ile przybywają do niego pielgrzymi. Kiedy ustaje napływ pielgrzymów, przestaje istnieć także sanktuarium.

5. Cechą charakterystyczną właściwą jedynie sanktuariom jest to, że przybywają tam wierni w pielgrzymce przyciągani przez konkretną przyczynę pobożności np. obrazy figury, albo relikwie, które cieszą

s. 120; J. Dudziak, Prawno-kanoniczna koncepcja, s. 68. Oczywiście najbardziej pożądaną byłaby aprobata „na piśmie”.

${ }^{61}$ Por. G. Feliciani, Santuario, s. 300.

${ }^{62}$ Régimen jurídico, s. 120.

${ }^{63}$ Por. X. Brossa, Régimen jurídico, s. 128.

${ }^{64}$ Odnośnie ordynariusza miejsca zob. kan. 134 KPK.

${ }^{65}$ X. Brossa, Régimen jurídico, s. 152. 
się specjalną czcią ludu, uzyskanie odpustów itd. Przyczyna ta musi wyzwalać i motywować pobożność wiernych tam się udających.

7. Każde sanktuarium potrzebuje do swego istnienia w sensie kanonicznym aprobaty kompetentnej władzy kościelnej: ordynariusza miejsca Konferencji Biskupów i Stolicy Apostolskiej.

\section{Around the legal definition of a shrine}

This article presents a holistic legal definition of a shrine, which is included in Can. 1230. First, the shrine as a church or other sacred place has been discussed. Next, the other part of the definition of the shrine as a target of numerous pilgrimages of believers has been presented. Another condition for the existence of the shrine is a special reason of piety. Finally, the constitution for establishing the shrine is, in the canonical sense, its approval by the competent ecclesiastical authority.

SŁowA KLUCZOWE: sanktuarium, kościół, miejsce święte, biskup, pielgrzymka, szczególna przyczyna pobożności

KEY WORDS: shrine, church, sacred place, bishop, pilgrimage, reason of special devotion 